\section{The Church of Charles Darwin (without Darwin)}

\author{
Mean Genes: From Sex to Money to Food: Taming Our Primal \\ Instincts \\ By Terry Burnham and Jay Phelan \\ Perseus Book Group, \$24.00, ISBN 0738202304, 2000 (hard cover) \\ Penguin USA, \$13.00, ISBN 0142000078, 2001 (paperback)
}

\section{Reviewed by Evan Balaban}

Neurosciences program CUNY college of Staten Island, Staten Island, New York 10314, USA

Hazel Motes, the main character of Flannery O'Connor's 1949 novel Wise Blood, sought to create a Church Without Christ, "where the blind don't see and the lame don't walk and what's dead stays that way." Terry Burnham and Jay Phelan would rather establish a Church of Darwin. To quote Burnham, "We take a page from the Freudian view that humans have a brain that is at war with itself. Almost everyone feels lusts in our hearts, stomachs, groins, and brains. Some of these lusts ought to be nurtured, while others will lead us to ruin if they are not controlled. So, Mean Genes takes the bold and novel step of offering advice to help people tame their passions (http://slate.msn.com).

Evolutionary psychologists and sociobiologists have an itch that Mean Genes tries to scratch. Despite having produced bestselling books at regular intervals for 25 years, their shared world view is not gaining widespread acceptance. Past writers have failed to follow the cardinal rule of Hoover Shoats, Hazel Motes's rival in Wise Blood, who counseled: "If you want to get anywheres in religion, you got to keep it sweet. You got good idears but what you need is an artist-type to work with you." Burnham (an economist) and Phelan (an evolutionary biologist) fill this 'artisttype' role by discarding complexities and nuances in favor of an acute single-mindedness of purpose. Readers seeking a traditional scholarly treatment on the causes of human behavior will be sorely disappointed, as the book favors a superficial and partisan treatment of complex issues, lacking any original synthesis of ideas.To judge the book on these grounds, however, would be unfair to its stated purpose. The authors have simply heeded another warning from the astute Shoats: "That's the trouble with you innerleckchuls, you don't never have nothing to show for what you're saying." They don't want to distract readers with too many messy details about the road to salvation before making their point: that Darwinism should tell you how to lead your everyday life.

Throughout the book, readers are often reminded that those devilishly mean genes, although powerful, are not our complete destiny; we need strong stuff to fight their effects. Mean Genes offers a factoidfilled carnival ride through contemporary culture's version of the seven deadly sins: money, laziness, fat, drugs, risk, greed and infidelity. Sections on sex differences, gender and sexual orientation, on beauty and on interpersonal relationships (relatives treated separately from non-relatives, of course) are added for good measure. The factoids are presented snappily and authoritatively (including references on a website); exposure to these brief arcana is the book's chief delight.

The difference between conjecture, contested interpretation and fact is seldom indicated. Counterexamples are not given, even when the authors cite genetic association studies that have failed to be replicated in several attempts antedating the book's publication. Instead, readers are given "the MG approach": (i) our brains and bodies were shaped by selection; this continues to affect our behavior via our genes (ii) these effects reflect (hypothetical) adaptations to former (hypothetically) stable conditions that have only recently (hypothetically) changed, and may not match current living conditions and (iii) we can find simple tricks to fool our brains and physiologies and attain personal happiness.
The strength of the book is its incisive, compact writing. Its weakness is its 'new contribution': the advice that is offered. This is banal, with little or no connection to genetics, evolutionary biology or the authors' explanatory arguments. For instance, readers plow through 193 pages of tidbits on sperm competition, parental investment theory, sex differences and cuckoldry to be told that to avoid marital strife, we need to make each marriage a 'sweet deal'. The net effect resembles the old joke about the pilgrim making great personal sacrifices to see an ascetic on a remote mountain top, only to be told that the secret of life is to carry a litterbag in the car.

In defense, Burnham has stated "In theory, you don't need Darwin to understand that you need to have a special television for taping and a different one for watching shows. Similarly, most of the tips in Mean Genes are not novel. In practice, however, it appears that embedding advice in the context of understanding 'human as animal' has helped me, Jay, and many readers to improve our lives. Without the underlying theory, readers must just blindly trust advice proffered in self-help books. Mean Genes may be the only self-help book you ever need because it teaches you the secret to generating real solutions. Attempts at self-improvement, without the light of evolution, are a pile of sundry 'tips."' This seems tantamount to saying that the Church of Darwin transforms people's lives only because it needs to cite Darwin for initial authority, or scientific validation, to ensure that the advice gets a hearing in the first place. Hazel Motes might feel right at home in this Church Without Darwin, at least until the first lawsuit rolls in from someone who believes that following the author's advice has ruined his or her life. In contrast with the self-help book competitors that Mean Genes hopes to make obsolete, I failed to find any legal disclaimer in its pages.

In spite of these shortcomings, Mean Genes succeeds at encapsulating a particular, controversial point of view about evolution and human behavior compactly and concisely. This could be an excellent tool for getting students to think about more constructive ways to link genetics and evolutionary biology to the study of behavior, and for highlighting critical issues in popularizing science and dealing with the integration of scientific information into our everyday lives. Whether you are inspired, entertained or enraged by it, you'll probably end up agreeing with a final piece of wisdom paraphrased from Hoover Shoats: "It don't make any difference how many Darwins you add to the name if you don't add nothing to the meaning, friend." 